\title{
Primary undifferentiated spindle cell sarcoma obstructing the right ventricular outflow tract
}

\author{
Jintae Kwon ${ }^{1 *}$ and Kyewon Kwon ${ }^{2}$
}

\begin{abstract}
Background: Primary undifferentiated spindle cell sarcoma in the right ventricle is an extremely rare tumor. Radical surgical excision is the optimal treatment for long-term survival due to poor response to chemotherapy or radiotherapy at an advanced stage.

Case presentation: A 42-year-old man with no previous medical history presented with mild dyspnea on exertion and abdominal distension that lasted a week. Computed tomography (CT) revealed a huge homogeneous mass completely obstructing the right ventricle and extending into the pulmonary trunk. However, he suddenly collapsed the next day while on his way to an echocardiography. An extracorporeal membrane oxygenation (ECMO) device was inserted percutaneously and ECMO support was urgently initiated. Based on consideration of right ventricular outflow tract (RVOT) obstruction in the initial CT scan, we decided to remove the mass from the right ventricle immediately. The main mass was resected to relieve the RVOT obstruction, and after the operation, the ECMO was removed from the operation room. However, the patient failed to regain consciousness and electroencephalography (EEG) and subsequent magnetic resonance imaging (MRI) indicated severe hypoxic brain damage. We assume CPR was unsuccessful because the mass completely blocked the RVOT. Pathology revealed the mass was an undifferentiated spindle cell sarcoma.
\end{abstract}

Conclusions: We present the case of a 42-year-old male with cardiac arrest due to right ventricular outflow tract obstruction by a tumor of the right ventricle. Surgical resection was performed and in histopathology it was proved to be an undifferentiated spindle cell sarcoma.

Keywords: Sarcoma, Right ventricular outflow tract, Spindle cell

\section{Background}

Although several atrial spindle cell sarcomas have reported, primary undifferentiated spindle cell sarcoma in the heart is a very rare tumor $[1,2]$. Radical surgical excision is the mainstay of treatment, but despite surgical resection, its prognosis is poor due to delayed diagnosis, early metastasis, and few available therapeutic options.

\footnotetext{
* Correspondence: acidum07@gmail.com

'Department of Thoracic and Cardiovascular Surgery, Bundang Jesaeng Hospital, Zip code: 13590, 20, Seohyeon-ro 180beon-gil, Bundang-gu, Seongnam-si, Gyeonggi-do, Republic of Korea

Full list of author information is available at the end of the article
}

\section{Case presentation}

A 42-year-old man with no previous medical history presented with mild dyspnea on exertion and abdominal distension that lasted for a week. Computed tomography (CT) revealed a huge homogeneous mass completely obstructing the right ventricle and extending into the pulmonary trunk (Fig. 1a, b). CT findings showed little evidence of blood clots and moderate amounts of pericardial effusion (Fig. 1b). The patient was admitted via the emergency room for further evaluation and scheduled for echocardiography the next day. However, he suddenly collapsed the next day while on his way to an

(c) The Author(s). 2020 Open Access This article is licensed under a Creative Commons Attribution 4.0 International License, which permits use, sharing, adaptation, distribution and reproduction in any medium or format, as long as you give appropriate credit to the original author(s) and the source, provide a link to the Creative Commons licence, and indicate if changes were made. The images or other third party material in this article are included in the article's Creative Commons licence, unless indicated otherwise in a credit line to the material. If material is not included in the article's Creative Commons licence and your intended use is not permitted by statutory regulation or exceeds the permitted use, you will need to obtain permission directly from the copyright holder. To view a copy of this licence, visit http://creativecommons.org/licenses/by/4.0/ The Creative Commons Public Domain Dedication waiver (http://creativecommons.org/publicdomain/zero/1.0/) applies to the data made available in this article, unless otherwise stated in a credit line to the data. 

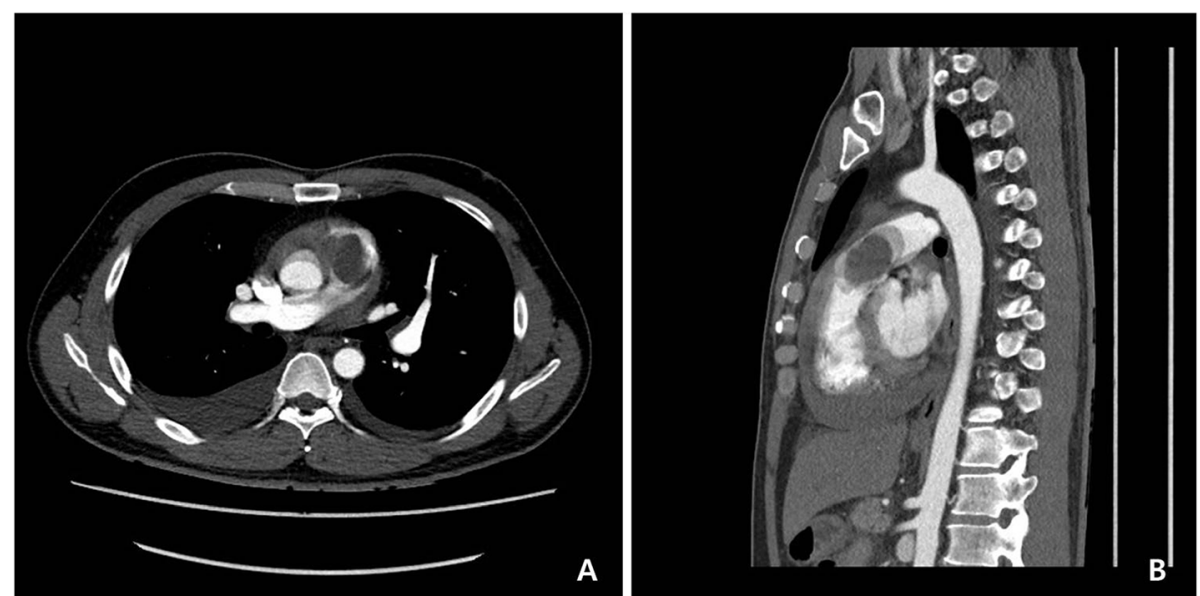

Fig. $1 \mathrm{CT}$ axial (a) and sagittal (b) images showing a mass completely obstructing the right ventricular outflow tract

echocardiography. Cardiopulmonary resuscitation (CPR) was performed immediately by medical staffs, but heart rhythm did not recover. Accordingly, an extracorporeal membrane oxygenation (ECMO) device was inserted percutaneously via the left femoral artery and right femoral vein and ECMO support was urgently initiated. Subsequently, a pericardial window was created at bedside, and about $350 \mathrm{cc}$ of dark blood colored effusion was drained. Soon afterward, blood pressure stabilized but consciousness was not confirmed. But his light reflexes remained intact. Based on consideration of right ventricular outflow tract (RVOT) obstruction in the initial CT scan, we decided to remove the mass from the right ventricle immediately. Surgery was performed using a median-sternotomy approach. Initially, an arterial cannula was placed in the distal aspect of the ascending aorta, and the superior and inferior venae cavae were cannulated to establish cardiopulmonary bypass $(\mathrm{CPB})$. After aortic cross-clamping, the pulmonary trunk and RVOT were incised. By intra-operative gross visualization, the tumor was located in the RVOT and protruded from endocardium of the right ventricle out of epicardium of the right ventricle (Fig. 2a) and also extended toward and was attached to the right leaflet of the pulmonary valve (Fig. 2b). The tumor was fragile and considered highly likely to be malignant and impossible to completely control, and thus, we planned chemotherapy after surgery. The main mass was resected to relieve the RVOT obstruction, and after the operation, the ECMO was removed from the operation
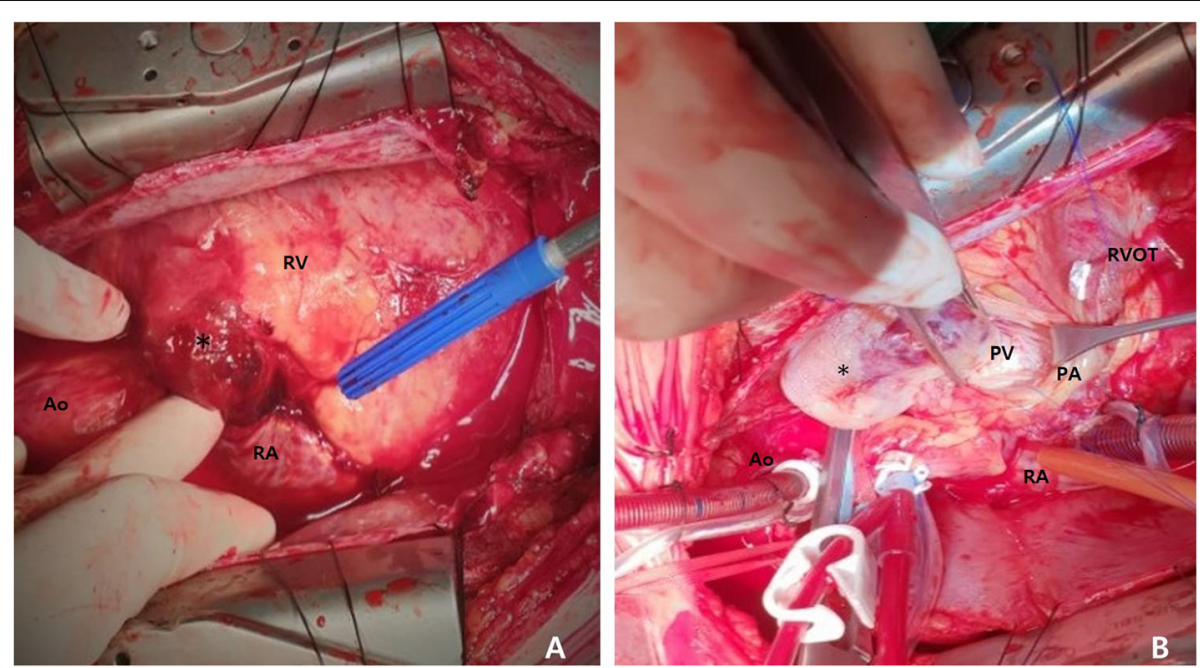

Fig. 2 Intraoperative photographs showing involvement (asterisk) of epicardium of the right ventricle (a) and the tumor (asterisk) located in the right ventricular outflow tract (b) Ao; ascending aorta, RA; right atrium, RV; right ventricle, RVOT; right ventricular outflow tract, PA; pulmonary artery, PV; pulmonic valve. 

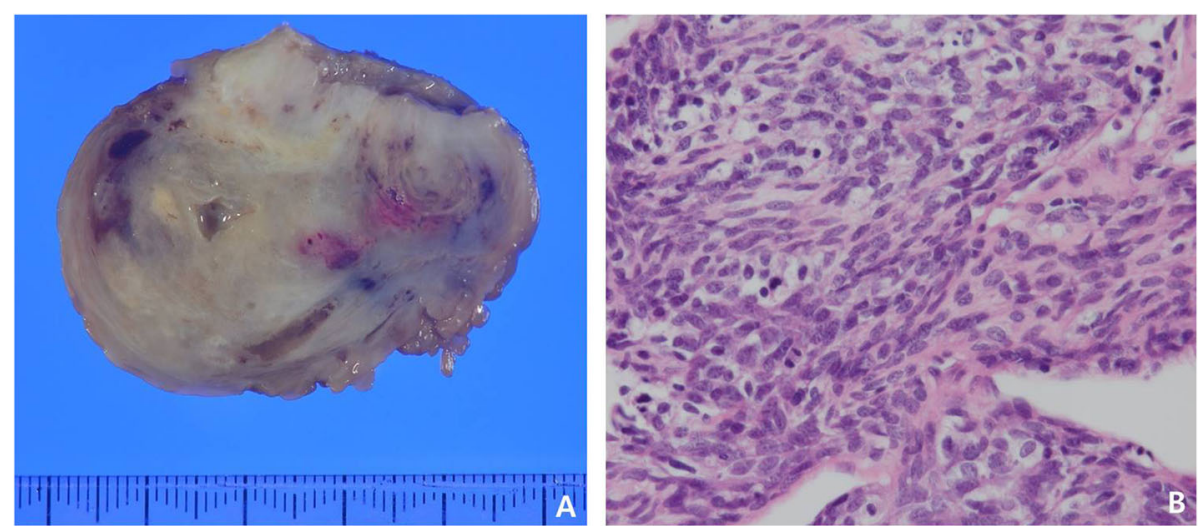

Fig. 3 Gross pathology of cardiac spindle cell sarcoma (a) and histopathology of cardiac spindle cell sarcoma (Hematoxylin and eosin stain, $\times 400)($ b)

room. However, the patient failed to regain consciousness and electroencephalography (EEG) and subsequent magnetic resonance imaging (MRI) indicated severe hypoxic brain damage. We assume CPR was unsuccessful because the mass completely blocked the RVOT. Pathology revealed the mass was an undifferentiated spindle cell sarcoma (Fig. 3a, b).

\section{Discussion and conclusions}

Twenty-five percent of primary cardiac tumors are malignant, and $95 \%$ of these are due to sarcoma [3]. Angiosarcoma is the most common type and accounts for around $40 \%$ of sarcomas, others include undifferentiated sarcoma (24\%), malignant fibrous histiocytoma (14$24 \%)$, leiomyosarcoma (8\%), osteosarcoma (6\%), and least of all, spindle cell sarcoma [1, 3, 4]. Cardiac sarcoma can present with sudden onset, intermittent or positional symptoms of chest discomfort, dyspnea, orthopnea, cough, or syncope, heart failure, pericardial effusion and tamponade, arrhythmias, valvular abnormalities, or obstructive symptoms depending on heart chamber involved. Diagnosis is usually established using non-invasive imaging modalities such as transthoracic or transesophageal echocardiography. CT and MRI are useful for complete assessment of tumors occupying the entire cardiac chamber, tumors infiltrating myocardium or pericardium, or tumors with adjacent great vessel involvement [5]. At time of diagnosis, up to $80 \%$ of spindle cell sarcomas exhibit evidence of metastasis [2]. Tumor emboli are common and cause distant metastases involving bone, peritoneum, liver, and mesenteric lymph nodes [2]. Furthermore, spindle cell sarcoma is a highly aggressive and can rapidly metastasize. In conclusion, we report a rare case of spindle cell sarcoma obstructing the right ventricular outflow tract. Although treatment of this neoplasm of heart remains challenging due to its rarity and aggressive nature, radical surgical excision remains the mainstay treatment.

\section{Abbreviations \\ CT: Computed tomography; CPR: Cardiopulmonary resuscitation; ECMO: extracorporeal membrane oxygenation; RVOT: right ventricular outflow tract; EEG: electroencephalography; MRI: magnetic resonance imaging; CPB: cardiopulmonary bypass}

\section{Acknowledgements \\ Not applicable.}

\section{Declarations}

Not applicable.

\section{Authors' contributions}

JTK was the principal author and principal investigator. KWK helped writing the case report as co-authors. All authors read and approved the final manuscript.

\section{Funding}

Not applicable.

Availability of data and materials

Not applicable.

\section{Ethics approval and consent to participate}

This case report was approved by the institutional review boards (approval number: 2020-02-001).

\section{Consent for publication}

We have consent from institutional review boards of Bundang Jesaeng hospital (Approval No. 2020-02-001).

\section{Competing interests}

The authors declare that they have no competing interests.

\section{Author details}

${ }^{1}$ Department of Thoracic and Cardiovascular Surgery, Bundang Jesaeng Hospital, Zip code: 13590, 20, Seohyeon-ro 180beon-gil, Bundang-gu, Seongnam-si, Gyeonggi-do, Republic of Korea. ${ }^{2}$ Department of Pathology, Bundang Jesaeng Hospital, Seongnam-si, Gyeonggi-do, Republic of Korea. 
Received: 1 February 2020 Accepted: 29 April 2020

Published online: 04 May 2020

\section{References}

1. Li Z, Hsieh T, Salehi A. Recurrent cardiac intimal (spindle cell) sarcoma of the left atrium. J Cardiothorac Vasc Anesth. 2013;27(1):103-7.

2. Ibrahim A, Luk A, Singhal P, et al. Primary intimal (spindle cell) sarcoma of the heart: a case report and review of the literature. Case Rep Med. 2013; 2013:461815.

3. Saric M, Armour AC, Arnaout MS, et al. Guidelines for the use of echocardiography in the evaluation of a cardiac source of embolism. J Am Soc Echocardiogr. 2016;29(1):1-42.

4. Butany J, Nair V, Naseemuddin A, Nair GM, Catton C, Yau T. Cardiac tumours: diagnosis and management. Lancet Oncol. 2005;6(4):219-28.

5. Araoz PA, Eklund HE, Welch TJ, Breen JF. CT and MR imaging of primary cardiac malignancies. Radiographics. 1999;19(6):1421-34.

\section{Publisher's Note}

Springer Nature remains neutral with regard to jurisdictional claims in published maps and institutional affiliations.

Ready to submit your research? Choose BMC and benefit from:

- fast, convenient online submission

- thorough peer review by experienced researchers in your field

- rapid publication on acceptance

- support for research data, including large and complex data types

- gold Open Access which fosters wider collaboration and increased citations

- maximum visibility for your research: over $100 \mathrm{M}$ website views per year

At BMC, research is always in progress.

Learn more biomedcentral.com/submissions 